How to cite this article:

Sultana, I., \& Rahman, M. M. (2020). Determinants of bank cost efficiency: Empirical evidence from Bangladesh. International Journal of Banking and Finance, 15(1), 39-71. https://doi.org/10.32890/ijbf2020.15.1.9931

\title{
Determinants of Bank Cost Efficiency: Empirical Evidence from Bangladesh
}

\author{
${ }^{1}$ Israth Sultana \\ ${ }^{2}$ Mohammad Morshedur Rahman \\ University of Chittagong, Chattogram, Bangladesh

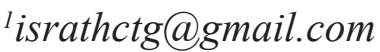 \\ 2Corresponding author:mmrais@cu.ac.bd;
}

A R T I C L E I N F O

Article history:

Received 8 October 2019

Revised 3 December 2019

Accepted 13 January 2020

Published 31 March 2020

Keywords:

Cost efficiency, risk,

capital regulation, banks, panel data.

JEL Code: C23, E22, G18, G21, G32, H2 1
A B S T R A C T

Due to the trust of depositors, banks should be responsible for efficient utilization of resources to achieve cost efficiency (CE) which in turn contributes to raising income. Previous studies found that the average $\mathrm{CE}$ of banks in Bangladesh was around $80 \%$. This study aims to find the determinants of $\mathrm{CE}$ in Bangladesh from a sample of 33 banks during a period from 2009 to 2016. Stochastic Frontier Approach (SFA) was used to measure $\mathrm{CE}$ in the first stage. In the second stage, different types of regression estimations were used like pooled ordinary least square, fixed effect or random effect panel regression, System-Dynamic Panel Data Estimation and Arellano-Bond Dynamic Panel Data Estimation for comparison. The results showed that Generalized Method of Moments (GMM) specifically the ArellanoBond Dynamic Panel Data Estimation was best suited for problems of 
endogeneity, serial correlation, heteroskedasticity and cross sectional dependence in data The results revealed that regulatory capital, risk measured by non-performing loan ratio, liquidity measured by total loans to total deposits, and level of operating costs had a significant negative impact on CE. In contrast, lagged cost efficiency, profitability, years of operation, net interest income had a significant positive impact on $\mathrm{CE}$. To attain competitive advantage by performing with higher $\mathrm{CE}$, policymakers should focus on capital regulation measured by capital adequacy ratio, risk level, profit earning capacity, aggressiveness of banks, bank size, years of operation and level of operating costs.

\section{Introduction}

In developing countries like Bangladesh, where people are interested in safe savings, the importance of commercial banks is immense. The trend of saving among people and likewise, the number of commercial banks have been increasing since independence. The banking industry in Bangladesh started with six nationalized commercial banks, three state owned specialized banks and nine foreign banks after independence. In the 1980s, the banking industry achieved significant expansion with the entry of private banks. Now there are 58 scheduled banks in Bangladesh which operate under the full control and supervision of the Bangladesh Bank, and recently three new banks have obtained permission to conduct their business. As there is intense rivalry among existing and upcoming banks, cost efficiency (CE) is an important concept to secure competitive advantage.

Commercial banks play an important role in maintaining stability and progress of the economy by properly mobilising financial resources across the country. Banks can increase economic growth and financial stability through efficient intermediation. On the other hand, if banks were inefficient then it would induce an economic crisis. Banna et al. (2017) argued that efficient banks can contribute not only to the productivity of the country but also lend more 
strength to the economy to fight against negative and external shocks. Therefore it can be said that efficiency in the banking sector of Bangladesh is crucial for economic growth and for the stability of the financial sector which leads to the stability of the whole economy.

Nowadays, CE is getting huge attention in improving bank performance including proper investment allocation. It is the way to save money by providing quality services in a better way. According to Ariff and Luc (2008) "CE refers to a firm's minimization of costs reflected by how close its cost is to what a best-practice firm would be for producing the same amount of outputs which are sold at certain prices with the given prices of inputs." In the context of banking, the measurement of efficiency is considered as a tool for taking management decisions regarding the improvement of bank performance and it provides bank specific information related to efficiency gain (Tecles \& Tabak, 2010).

However, Ab-Rahim et al. (2012) argued that banks, within a competitive environment, need to examine their performance for survival which is dependent on their productive efficiencies. Blejer (2006) claimed that the capability of emerging markets for adoption of optimal stabilization policies is impeded due to inefficiencies, financial instability and financial market imperfection. The study also added that financial efficiency is the basis for the success of any economy; hence an emerging economy should emphasize financial efficiency which would lead to financial stability. Schumpeter (1982) concluded that the economy would be better if it has a more efficient financial system.

Therefore, a better allocation of financial resources is embodied in the improvement of banking performance. As a result, the economy will attract more private investments that lead to economic growth. In recent years, the income of the people of Bangladesh has been increasing and since most of the people of this country are risk averse, banking operations should continue to grow. In addition, banks also need to show their performance in a better way to attain the confidence of depositors. Although the economy is largely dependent on the financial system, Bangladesh has been facing challenges in stimulating private investments for a long period of time. The banking industry in Bangladesh is undergoing a critical time due to some deregulation and non-performing loans. The government has earmarked the financial sector as a major area to be developed for the development of the whole economy. Some banks are striving hard to remain competitive. In order to thrive in the modern competitive business world, these banks need to focus attention on their performance. In this regard, the performance measurement of banks is important.

Evaluation of banking efficiency is valuable from both the microeconomic and macroeconomic perspective (Berger \& Mester, 1997). From the microeconomic view point, inefficiency in the banking system is vital because competition is stiff and there is a huge development in banking institutions, regulations and supervision. On the other hand, from the macroeconomic view 
point, the soundness of the financial market and the cost of intermediation are being influenced by efficiency of the banking sector (Ab-Rahim et al., 2012). The existing literature is divided into three categories: event studies, operating performance studies through ratio analysis and frontier analysis studies. Event studies are basically conducted to show the impact of an event, for example, merger to the value of shareholders. Operating performance studies are conducted based on ratio analysis which allows for comparison of different sized banks. Both of these approaches have been criticized due to their limitations (Koher et al., 2000; Nail \& Parisi, 2005). To overcome these limitations, this study uses Stochastic Frontier Analysis (SFA) to measure banking CE.

In addition, when banks are less cost efficienct, the risk of failure will be higher, which may in turn, lead the economy of the country to depression (Podpiera \& Podpiera, 2005). As a small and developing country, if a bank fails, the government of Bangladesh has little capacity to support the banking sector. Therefore, the difference between successful and inefficient banks should be identified (Hassan \& Hassan, 2018). Moreover, The Central Bank of Bangladesh emphasized the need for an efficient banking sector. Thus, the authorities urged that more research be conducted on the banking sector of Bangladesh (Khanam \& Nghiem, 2006). There are very few studies focused on CE in Bangladeshi banks and those studies found that the average CE in Bangladesh was around $80 \%$ (Hassan \& Hassan, 2018: Khanam \& Nghiem, 2006). They argued that the CE of banks should be improved. It is not sufficient to ascertain efficient and inefficient banks without knowing what factors are working behind a bank's CE. To fulfill that need, determinants of a bank's CE should be identified. Moreover, BASEL I, II, III capital regulations have been implemented in Bangladesh to mitigate the risk taking behavior of banks in Bangladesh. With the introduction of capital regulation and based on the risk taking behavior of banks in Bangladesh, the impact of this capital regulation along with the risk on CE of banks in Bangladesh need to be examined.

There are several studies conducted on CE of commercial banks in the context of developed countries, but there are not many studies conducted in the context of developing or least developed countries. Based on our knowledge, there is no empirical study in Bangladesh on this issue. Therefore our objective is to contribute to the existing literature by examining the determinants of $\mathrm{CE}$ of 33 Bangladeshi commercial banks spanning the period from 2009 to 2016. Specifically, this study looks into the impact of capital regulation, risk-taking behavior and relevant factors that influence a bank's CE. Moreover, as tasks in banks are repetitive in nature, the learning curve and experience curve can be applied in Bangladesh for reducing and managing operating cost in banks thereby increasing CE (Fioretti, 2007; Teplitz, 1991; Wright, 1936). Bush (2015) suggested that experience is related to $\mathrm{CE}$ gains in the banking sector. Boot and 
Thakor (1997) found that efficiency achieved from experience may reduce labor cost in cases of similar types of loan monitoring. Hence, the study also explores the impact of experience and learning on CE.

The rest of the paper is organized as follows: section 2 reviews the literature and provides testable hypotheses. Section 3 introduces the research methodology. Section 4 presents the empirical results and reports on the robustness of testing, and section 5 concludes the study with recommendations.

\section{Literature Review and Hypotheses Development}

There is a large number of studies both on single countries as well as on cross countries that focused on banking efficiency. Hereafter, we briefly report previous studies that covered the CE of banks and the factors of CE in both developed and developing countries. Financial instability, inefficiencies, and financial market imperfections hamper the adoption of stabilization policies in emerging markets. It is argued that the financial regulatory paradigm, embodied in Basel, may improve financial stability but reinforces cyclicality (Blejer, 2006). The study concluded that emphasis should be given on financial efficiency because it will enhance financial stability without increasing cyclicality.

The literature on banks' CE can be divided into two groups. In the first group, we report on a number of studies that focused on the identification of the impact of various specific measures of transition like capital structure, capital measure, risk measure, ownership structure, banking reform, economic reform, financial liberalization and financial crisis, etc., on CE in a number of countries (Spulbăr \& Niţoi, 2014). In the second group, we report on studies that focused on the determinants of $\mathrm{CE}$.

\subsection{Literature on Impact of Various Measures of Transition on CE}

Among the previous studies in this group, Abdul-Majid et al. (2011a) found that the East Asian financial crisis caused a short-term increase in efficiency. The study also concluded that bank efficiency declined because conventional banks were operating under Islamic banking windows. Their findings were also supported by a study from Hammim et al. (2006).

In another study, Abdul-Majid et al. (2011b) showed the impact of Islamic banking on $\mathrm{CE}$ and found that higher inputs were required for Islamic banks. The study also concluded that merged banks used higher input and the financial crisis showed a negative impact on bank performance in the increasing volume of nonperforming loans. Alam (2012) focused on the impact of regulatory and supervisory structures on efficiency and found that regulations, strict monitoring 
of banking operations and higher supervisory power of the authorities increased the efficiency of Islamic banks but decreased the efficiency of conventional banks. The results also supported the findings of Chortareas et al. (2012).

The existence of competition-efficiency hypothesis was confirmed in studies by Andrieş and Căpraru (2014) and Kyj and Isik (2008). Hall and Simper (2013) found evidence that perfect competition prevailed in Korean banking which offered a basis for merger policy where there were scale economies to be obtained and reduction in average costs that enhanced efficiency. By working on Chinese banks, Ariff and Luc (2008) suggested that joint-stock banks were more $\mathrm{CE}$ than state-owned banks. Banking reforms also played a vital role in changing banking efficiency. Ataullah and Le (2006) focused on banking reforms in Indian banking and suggested that banking efficiency increased due to economic reforms in India. The study also found that fiscal deficit negatively influenced bank efficiency.

Beyond the above studies, Avkiran (2011) suggested that financial ratios can be predicted by regressing ratios on efficiency estimates. The study also reported that Data Envelopment Analysis (DEA) can also be used to objectively identify benchmarks for ratio analysis based on actual observed data collected from peers where an input-output specification consisted of key financial ratios. The heterogeneity of environmental conditions calls for the consideration of efficiency measurement (Battaglia et al., 2010). The study showed that environmental conditions substantially influenced efficiency estimates.

In addition, Battese et al. (2000), Das and Ghosh (2009) focused on efficiency in the deregulation of the Swedish and Indian banking industry, respectively. The study found significant technical inefficiency of labor used in Swedish banks. On the other hand, environmental conditions of a country play an important role in the definition and specification of the common frontier in different countries (Dietsch \& Lozano-Vivas, 2000). The study suggested that environmental variables significantly affected the difference in efficiency for French and Spanish banking industries. In another study, Esho (2001) argued that estimates of CE and efficiency ranking would be biased if subsidies were ignored.

Despite the above, Hasan and Marton (2003) analyzed the experiences and developments of the banking sector during the transitional process. The study suggested that flexible techniques to privatization, easy policy for foreign banks and early reorganization initiatives induced the development of a comparatively stable banking system thus raising efficiency. The study also concluded that foreign banks and banks with higher foreign bank ownership showed lower inefficiency. The finding was also supported by findings from Kasman and Yildirim (2006). In addition, Hauner (2005) found that state-owned banks in Germany and Austria were more cost efficient. 


\section{$2.2 \quad$ Literature on Determinants of CE}

A number of other studies have focused on the determinants of bank $\mathrm{CE}$ which included bank-level variables like capital ratio, risk level, bank size, liquidity, performance, years of operation, loan loss provision, non-performing loans, etc., and macroeconomic variables such as growth in gross domestic product, inflation, banking sector development, etc. With regard to bank level factors, a number of studies were conducted on both developing and developed countries. Those studies found that government ownership, population density, demand density, credit risk, liquidity ratio, solvency ratio, bank size, equity to total assets and market concentration resulted in positive impact on different measures of efficiency and also CE (Ab-Rahim et al., 2012; Chan et al., 2014; Girardone et al., 2004).

On the other hand, off balance sheet exposure, interest sensitivity, merger, macroeconomic conditions, capitalization, credit risk, asset quality and management quality, and problem loans resulted in a negative impact on different measures of efficiency and also CE (Ab-Rahim et al., 2012; Berger \& DeYoung, 1997; Chan et al., 2014; Chang \& Chiu, 2006; Chiu et al., 2008; Drake \& Hall, 2003; Garza-Garcia, 2012; Girardone et al., 2004).

In addition, mixed results were also found regarding the $\mathrm{CE}$ determinants of banks. For example, Chang and Chiu (2006) argued that risk factors impacted bank efficiency. The study also found no significant difference with bank efficiency index when it only considered market or credit risk. Finally, the study concluded that different risk based bank efficiency were influenced by different factors. Other than the studies mentioned, Chan et al. (2014) found that bank insolvency risk (as measured by z-scores) was positively related to efficiency. In a study, Chiu et al. (2008) showed that capital adequacy was an influential factor in evaluating the efficiency of banks and highly capitalized banks had average efficiency scores which were significantly higher than those of low capitalized banks.In a study, Christopoulos et al. (2002) showed that smaller banks were more efficient than larger ones. The study also found that bank loans, investment and economic performance were positively related to the $\mathrm{CE}$ of the Greek commercial banking sector. In another study, Das and Ghosh (2009) reflected that inefficiency was important on the revenue side of banking activity. The study also revealed that allocative inefficiency took a larger portion of outlay cost. The study also suggested that other than the factors mentioned, product diversity and prudential indicators were important variables that drove efficiency.

Eisazadeh and Shaeri (2012) also found other factors that affected efficiency. These were: financial development, the degree of market competition, macroeconomic stability, legal rights and contract laws, political stability and better governance. The study recommended to build stronger institutions, improve governance and promote more competition. In addition, age, average deposit size and interest rate spreads also contributed to CE (Esho, 2001). 
In another study, Fries and Taci (2005) revealed that there was a non-linear relationship between progress in banking reform and $\mathrm{CE}$. The study focused on the transformation of banking in the post-communist transition in European countries and found that banks with large foreign shares had lower costs and state-owned banks were less efficient than private banks. Private banks with foreign ownership were more CE (Garza-García, 2012). In contrast, Gardener et al. (2011) found that state-owned banks were more efficient than those of private banks.

In terms of macroeconomic variable, a positive association was found between GDP and CE (Chan et al., 2014; Garza-García, 2012). In terms of efficiency, a number of studies used X-efficiency as a proxy for efficiency, for example, Altunbaş et al. (2001), Altunbas et al. (2000), Isik and Hassan (2003), Kenjegalieva et al. (2009), Kraft and Tirtıroğlu (1998) and Kyj and Isik (2008).

Based on the literature, we selected the following variables as the potential factors of banks' CE: capital ratio, risk, performance, years of operation, level of operating costs, size of bank, lagged CE, number of bank branches, ownership structure, etc. and the following alternative hypotheses were developed:

H1 : More capital makes the bank more cost efficient. (Capital has a positive relationship with bank $\mathrm{CE}$.)

H2 : Risky banks are less cost efficient. (Bank CE is negatively related to risk profile.)

H3 : Profitable banks are cost efficient. (The relationship between bank cost efficiency and bank profitability is positive.)

H4 : Experienced banks are more cost efficient. (Age of bank is positively related to bank cost efficiency.)

H5 : Banks with high operating cost are less cost efficient. (There is a negative correlation between operating cost and cost efficiency.).

H6 : Large banks (in terms of assets) are most cost efficient. (Bank size is positively correlated with cost efficiency.)

H7 : Efficient banks may remain efficient. (Previous year efficiency is positively related to current efficiency.)

\subsection{Literature on CE, Risk, Capital Regulation and Bank Performance}

A significant number of studies were focused on efficiency along with risk, capital regulation and performance, for example, Altunbas et al. (2007), Altunbas et al. (2000), Bitar et al. (2018), Chan et al. (2014), Deelchand and Padgett (2009b), Faccio et al. (2016), Färe et al. (2004), Fethi and Pasiouras (2010), Fiordelisi and Mare (2013), Fiordelisi et al. (2011), Koetter (2008), Kwan and Eisenbeis (1997), Zhang et al. (2012) and Sarkar et al. (2019). 


\subsection{Literature on CE in Developed Countries}

In the context of developed countries, Altunbaş et al. (2001), Altunbas et al. (2007), Andrieş and Căpraru (2014), Chortareas et al. (2012), and Fiordelisi et al. (2011) investigated European banks, Altunbas et al. (2000), Deelchand and Padgett (2009b), Drake and Hall (2003) examined Japanese banks, Carvallo and Kasman (2005) researched on North American and Caribbean banks, Chortareas et al. (2009), Christopoulos et al. (2002), Chortareas et al. (2009) investigated Greek banks, Čiković and Cvetkoska (2018) studied the Macedonian banking sector, Kumbhakar and Tsionas (2008), Färe et al. (2004) investigated the US banking industry, Carvallo and Kasman (2005) researched on banks in Latin America, Dietsch and Lozano-Vivas (2000) examined French and Spanish banks, Esho (2001) investigated Australian banks, Fiordelisi and Mare (2013) on Italian banks, Garza-García (2012) researched on banks in Mexico and Eisazadeh and Shaeri (2012) studied banks in African countries.

\subsection{Literature on $C E$ in Asian Countries}

In Asian countries, Abdul-Majid et al. (2011a), Abdul-Majid et al. (2011b), AbRahim et al. (2012) researched on Malaysian banks, Anwar (2015) investigated Indonesian banks, Ariff and Luc (2008), Avkiran (2011), Berger et al. (2009), Dong et al. (2014) examined Chinese banks, Chiu et al. (2008), Chang and Chiu (2006), Chiu et al. (2011) studied banks in Taiwan, Ataullah and Le (2006) examined Indian banks, Bitar et al. (2018) researched on banks in OECD countries and Hall and Simper (2013) investigated Korean banks. While studies by Aliyu and Yusof (2016), Bitar et al. (2018), Chan et al. (2014), Chortareas et al. (2012), and Gardener et al. (2011) were based on cross countries.

Among the studies conducted in Bangladesh, Zheng et al. (2018) assessed the effect of human capital efficiency on bank risk and capital regulation. The study found a significant positive association between risk and human capital efficiency; in contrast, the relationship was negative with capital. Miah and Sharmeen (2015) examined the relationship between capital, risk and efficiency when comparing Islamic banks with traditional banks. Their study showed that conventional banks were more efficient in managing costs.

\subsection{Literature on Research Methods Used in CE}

With regards to the calculation of efficiency, some studies used DEA for example, Ab-Rahim et al. (2012), Anwar (2015), Ataullah and Le (2006), Avkiran (2006), Avkiran (2011), Chang and Chiu (2006), Chiu et al. (2011), Chortareas et al. (2009), Chortareas et al. (2012), Christopoulos et al. (2002), Čiković and Cvetkoska (2018), Das and Ghosh (2009), Dong et al. (2014), Fethi 
and Pasiouras (2010) and Gardener et al. (2011). In some other studies, SFA was used, for example, Abdul-Majid et al. (2011b), Anwar (2015), Battaglia et al. (2010), Dong et al. (2014), Esho (2001), Miah and Sharmeen (2015), Zheng et al. (2018).

In the second stage regression analysis, a majority of the studies used Tobit regression, Berger and DeYoung (1997) used Granger Causality technique, Deelchand and Padgett (2009b), and Garza-García (2012) used two stage least square regression, Miah and Sharmeen (2015) used seemingly unrelated regression technique. Only a few studies used GMM, for example, Han et al. (2012), Ataullah and Le (2006), and Zheng et al. (2018).

Anwar (2015) suggested that DEA should be used for estimating technical efficiency and SFA be used for cost efficiency. Avkiran (2006) argued that "DEA identifies the inefficiency in a particular decision making unit (DMU) by comparing it to similar DMUs regarded as efficient, rather than trying to associate a DMU's performance with statistical averages that may not be applicable to that DMU."

In accordance with the studies of Anwar (2015) and Avkiran (2006), our study has contributed to the existing literature by integrating determinants of banking efficiency into the areas of SFA methodology in the 1st stage and GMM in the 2 nd stage regression analysis in the context of Bangladeshi banking system across individual domestic banks. We applied dynamic panel GMM technique (Doytch \& Uctum, 2011) to correct potential endogeneity, heteroscedasticity, cross section dependence and autocorrelation problems. In addition, banks can learn from experience and can increase CE through learning and experience. However, this is not evident in the literature. Hence, we have also contributed to the existing literature by focusing on the learning and experience theory which is rarely focused in the literature.

\section{Methodology}

\subsection{Data and Sources}

On 31st December 2016, there were 58 commercial banks operating their businesses in Bangladesh. Among them six were state owned commercial banks, three were state-owned specialized banks, 40 were private commercial banks and nine were foreign commercial banks (Annual report of Bangladesh Bank). Initially the sample consisted of 58 banks. Three specialized banks were excluded because of their non-involvement in commercial activities. Due to the lack of available data, we also excluded nine foreign commercial banks. A total of 13 commercial banks were also excluded from the sample because they were either new or that data were not available. In fine-tuning, the final sample consisted of 33 Bangladeshi commercial banks for the period from 2009 to 2016 including 
four state owned commercial banks. The study was based on secondary data. These data were drawn from the annual published reports of respective banks and from their websites.

\subsection{Measurement of Variables}

\subsubsection{Dependent Variable}

Cost technical efficiency is the dependent variable in this study. SFA was used to calculate CE. Total cost is the dependent variable in the SFA model and a number of inputs and outputs were used to calculate CE. The SFA used to calculate the efficiency of each bank in this study was based on the stochastic frontier production methodology which was originated by Aigner et al. (1977). The stochastic cost frontier model was developed (Kwan \& Eisenbeis, 1997; Schmidt \& Lovell, 1979) based on the production frontier model. According to this methodology, due to inefficiency and random noise in the observed cost of a bank, the following is formulated to deviate from cost-efficient frontier (Deelchand \& Padgett, 2009a). For the $\mathrm{n}^{\text {th }}$ bank,

$$
\ln \mathrm{TC}_{\mathrm{n}}=\mathrm{f}\left(\ln \mathrm{Q}_{\mathrm{i}}, \ln \mathrm{P}_{\mathrm{j}}\right)+\varepsilon_{\mathrm{n}}
$$

Where, $\mathrm{TC}_{\mathrm{n}}$ represents total operating cost including financial costs, $\mathrm{Q}_{\mathrm{i}}$ indicates outputs, $\mathrm{Pj}$ stands for input, $\varepsilon_{\mathrm{n}}$ shows the deviation of actual total cost of a bank from the cost-efficient frontier. Table 1 shows the list of input and output variables used in the calculation of $\mathrm{CE}$.

Table 1. Description of Input and Output Variables Used in the Calculation of CE

\begin{tabular}{|c|c|c|}
\hline Variable & Definition & Source \\
\hline $\begin{array}{l}\text { Dependent variable, Total } \\
\text { Cost (TC) }\end{array}$ & $\begin{array}{l}\text { Operating cost } \\
\text { including interest } \\
\text { expenses }\end{array}$ & Used in all previous studies \\
\hline Loans $\left(Q_{1}\right)$ & $\begin{array}{l}\text { Total loan and } \\
\text { advances }\end{array}$ & $\begin{array}{l}\text { Dong et al. (2014), Xiaoqing } \\
\text { Maggie and Heffernan (2007), } \\
\text { Manlagñit (2011) }\end{array}$ \\
\hline $\begin{array}{l}\text { Total } \\
\text { deposits }\left(Q_{2}\right)\end{array}$ & Total deposits & $\begin{array}{l}\text { Xiaoqing Maggie } \\
\text { Heffernan (2007) }\end{array}$ \\
\hline $\begin{array}{l}\text { Other earning } \\
\operatorname{assets}\left(Q_{3}\right)\end{array}$ & $\begin{array}{l}\text { Total assets net } \\
\text { off total loans and } \\
\text { fixed assets }\end{array}$ & Dong et al. (2014) \\
\hline
\end{tabular}




\begin{tabular}{|c|c|c|c|}
\hline Variable & & Definition & Source \\
\hline \multirow[t]{3}{*}{ Outputs } & $\begin{array}{l}\text { Non-interest } \\
\text { income }\left(Q_{4}\right)\end{array}$ & $\begin{array}{l}\text { Income other than } \\
\text { interest on loan } \\
\text { and advances }\end{array}$ & $\begin{array}{l}\text { Dong et al. (2014), Xiaoqing } \\
\text { Maggie and Heffernan (2007) }\end{array}$ \\
\hline & $\begin{array}{l}\text { Off-balance } \\
\text { sheet items }\left(Q_{5}\right)\end{array}$ & $\begin{array}{l}\text { Off-balance sheet } \\
\text { commitments and } \\
\text { contingencies }\end{array}$ & Manlagñit (2011) \\
\hline & $\begin{array}{l}\text { Price of labor } \\
\left(\mathrm{P}_{1}\right)\end{array}$ & $\begin{array}{l}\text { Ratio of staff } \\
\text { expenses and } \\
\text { number of } \\
\text { employees }\end{array}$ & $\begin{array}{l}\text { Berger and Hannan (1998), } \\
\text { Dong et al. (2014), Xiaoqing } \\
\text { Maggie and Heffernan (2007), } \\
\text { Manlagñit (2011) }\end{array}$ \\
\hline \multirow[t]{2}{*}{ Inputs } & $\begin{array}{l}\text { Price of } \\
\operatorname{deposits}\left(\mathrm{P}_{2}\right)\end{array}$ & $\begin{array}{l}\text { Ratio of interest } \\
\text { expenses and total } \\
\text { customer deposits }\end{array}$ & $\begin{array}{l}\text { Dong et al. (2014), Xiaoqing } \\
\text { Maggie and Heffernan (2007), } \\
\text { Manlagñit (2011) }\end{array}$ \\
\hline & $\begin{array}{l}\text { Price of } \\
\text { physical } \\
\text { capital }\left(\mathrm{P}_{3}\right)\end{array}$ & $\begin{array}{l}\text { Ratio of other non- } \\
\text { interest expenses } \\
\text { and physical } \\
\text { capital. }\end{array}$ & $\begin{array}{l}\text { Dong et al. (2014), Xiaoqing } \\
\text { Maggie and Heffernan (2007), } \\
\text { Manlagñit (2011) }\end{array}$ \\
\hline
\end{tabular}

Error term has two disturbance terms given as follows:

$$
\varepsilon_{\mathrm{n}}=\mathrm{U}_{\mathrm{n}}+\mathrm{V}_{\mathrm{n}}
$$

Where, $\mathrm{V}_{\mathrm{n}}$ is the random error term and it is also known as the twosided noise component and we assume that this is independent and identically distributed $\mathrm{N}\left(0, \sigma_{v}^{2}\right)$. $\mathrm{V}_{\mathrm{n}}$ refers to the stochastic nature of the cost function. $\mathrm{U}_{\mathrm{n}}$ represents the nonnegative disturbance which indicates deviation from the efficient cost frontier of individual banks and serves as a proxy for technical efficiency and assumed to be distributed independently of $\mathrm{V}_{\mathrm{n}}$ and follows a halfnormal distribution or truncated normal distribution i.e. $\mathrm{N}\left(0, \sigma_{u}^{2}\right)$. The notation $\mathrm{N}\left(0, \sigma_{u}^{2}\right)$ and $\mathrm{N}\left(0, \sigma_{v}^{2}\right)$ mean normally distributed with zero mean and variance. By using intermediation approach (Sealey \& Lindley, 1977) and by following Deelchand and Padgett (2009a), we developed the following multiproduct trans $\log$ cost function to specify the cost function:

$$
\begin{aligned}
& \operatorname{lnTC}=\alpha+\sum_{i} \alpha_{i} \ln Q_{i}+\sum_{j} \beta_{j} \ln P_{j}+1 / 2 \sum_{i} \Sigma_{k} \gamma_{i k} \ln Q_{i} \ln Q_{k}+1 / 2 \\
& \sum_{j} \Sigma_{h} \delta_{j h} \ln P_{j} \ln P_{h}+\sum_{i} \Sigma_{j} \lambda_{i j} \ln Q_{i} \ln P_{j}+
\end{aligned}
$$

According to Jondrow et al. (1982), the expected value of $U_{n}$, on conditional $\varepsilon_{\mathrm{n}}$, represents the cost-inefficiency of bank $\mathrm{n}$ (which is defined as $\mathrm{C}_{\mathrm{n}}$ ).

$$
C_{n}=E U_{n} / \varepsilon_{n}=\left[\sigma \lambda /\left(1+\lambda^{2}\right]\left[\varphi\left(\varepsilon_{n} \lambda / \sigma\right) / \phi\left(\varepsilon_{n} \lambda / \sigma\right)+\varepsilon_{n} \lambda / \sigma\right]\right.
$$


Where, $\lambda$ is the ratio of the standard deviation of $U_{n}$ to standard deviation of $\mathrm{V}_{\mathrm{n}}, \varphi$ is the cumulative standard normal density function, and $\phi$ is the standard normal density function. $\mathrm{C}_{\mathrm{n}}$ can be estimated by using equation (3). We used computer software called Frontier Version 4.1 developed by Coelli (1996) for Stochastic Frontier Production and cost function was estimated by the method of maximum likelihood.

\subsubsection{Independent Variables: Determinants of CE}

The potential determinants of bank cost efficiency are enumerated in this section. Table 2 represents the circumstantial variables used in the study. We considered only the bank specific variables in our study. As mentioned in the literature part, based on previous studies as well as theoretical background we selected a number of bank specific variables which included capital ratio, risk level, profitability, bank size, total loans to total deposits, ownership dummy, operating expenses, non-interest income, number of branches and years of operation as potential determinants of CE.

Capital ratio was measured by using capital adequacy ratio (CAR) as required by BASEL capital regulation, It is noted that, commercial banks in Bangladesh have to maintain a capital of TK 4,000 million or $10 \%$ on risk weighted assets, whichever is higher. Secondly, to see the impact of risk profile (Risk) we considered the ratio of non-performing loans to total loans (NPLTL) as a proxy for risk. In a third world country like Bangladesh, banks which provide more loans, are expected to have high credit risk. It is expected that NPLTL has a negative effect on CE. In accordance with previous studies, ownership structure represented by OWND was taken as the independent variable to see its impact on CE. If the bank is a private commercial bank, then the OWND equals 1 and otherwise, 0 . In some studies it was found that state owned commercial banks were more efficient whereas in other studies, it was the private commercial banks which were more efficient. Therefore, there is no clear opinion on this variable.

To determine whether more profitable banks were more cost efficient, return on assets (ROA) was used to see the impact of profitability. Nowadays, banks provide fee-based services. We used non interest income to total assets (NIITA) as a proxy to see the impact of this fee-based service on CE. In Bangladesh, this type of banking activities is still not very much popular. Since generating income from this new service line may be costly, that is why, in some cases its correlation with bank CE can be mixed. To see the impact of lending propensity on CE we used the ratio of total loans to total deposits (TLTD) as a proxy for lending propensity. The bank which lends more can generate more income in return. So, it is expected to have a positive effect on bank CE. It is expected that as banks grow they can perform efficiently. To examine the impact of experience of banks in $\mathrm{CE}$,we used number of years in operation (Age) as a proxy to measure experience and we expect that banks with more 
years in operation are more CE. To see the impact of bank size we considered natural logarithm of total assets (Size). Some authors found that small banks were more cost inefficient than large banks. Some other authors found that both small and large banks were cost efficient. It is expected that bank size has a positive effect on CE. It was found in the literature that banks with higher levels of operating costs were less cost efficient. Hence, we considered the level of operating cost (OC) to observe its impact on $\mathrm{CE}$. It is expected to have a negative association between them. Finally, to see whether banks with a high number of branches are cost efficient or not, we considered a number of branches (NB) as a potential determinant of $\mathrm{CE}$. To see whether $\mathrm{CE}$ showed persistence results we considered $\mathrm{CE}$ in the last year or lagged $\mathrm{CE}$ which is proxied as $\mathrm{CE}(-1)$ as a potential determinant of $\mathrm{CE}$. We expected a positive relationship between lagged $\mathrm{CE}$ and $\mathrm{CE}$.

Table 2. Description of Variables Used in the Study

\begin{tabular}{|c|c|c|}
\hline Variable & Definition & Source \\
\hline $\begin{array}{l}\text { Cost Efficiency } \\
\text { (CE) }\end{array}$ & Calculated from SFA & $\begin{array}{l}\text { Hafez (2018); Zheng et al. (2018); Tecles } \\
\text { and Tabak (2010) }\end{array}$ \\
\hline Capital (CAR) & $\begin{array}{l}\text { Ratio of capital to } \\
\text { risk-weighted assets } \\
\text { (Tier } 1 \text { Capital + Tier } \\
2 \text { Capital) / Risky } \\
\text { weighted assets }\end{array}$ & $\begin{array}{l}\text { Hafez (2018); Avkiran (2011); Hughes and } \\
\text { Mester (2008); Chang and Chiu (2006) }\end{array}$ \\
\hline Risk (NPLTL) & $\begin{array}{l}\text { Non performing loan } \\
\text { to total loan }\end{array}$ & $\begin{array}{l}\text { Carvallo and Kasman (2005); Lee et al. } \\
\text { (2014); Zheng et al. (2018) }\end{array}$ \\
\hline $\begin{array}{l}\text { Profitability } \\
\text { (ROA) }\end{array}$ & Return on total asset & $\begin{array}{l}\text { Sun and Chang (2011); Vennet (2002); } \\
\text { Ariff and Luc (2008); Maudos et al. (2002); } \\
\text { Ray and Das (2010) }\end{array}$ \\
\hline Size (Size) & $\begin{array}{l}\text { Natural logarithm of } \\
\text { total asset }\end{array}$ & $\begin{array}{l}\text { Tecles and Tabak (2010); Wezel (2010); } \\
\text { Ariff and Luc (2008); Girardone et al. } \\
\text { (2004); Carvallo and Kasman (2005); } \\
\text { Staikouras et al. (2008) }\end{array}$ \\
\hline $\begin{array}{l}\text { Total loan to total } \\
\text { deposit (TLTD) }\end{array}$ & $\begin{array}{l}\text { The ratio of total loan } \\
\text { to total deposit }\end{array}$ & Anwar (2015) \\
\hline $\begin{array}{l}\text { Ownership } \\
\text { (OWND) }\end{array}$ & $\begin{array}{l}\text { OWND equals } 1 \text { if } \\
\text { the bank is a private } \\
\text { commercial bank } \\
\text { and } 0 \text { otherwise }\end{array}$ & $\begin{array}{l}\text { Ariff and Luc (2008), Xiaoqing Maggie } \\
\text { and Heffernan (2007); Xiaogang et al. } \\
\text { (2005); Schulz et al. (2009) }\end{array}$ \\
\hline $\begin{array}{l}\text { Operating } \\
\text { expenses (OC) }\end{array}$ & $\begin{array}{l}\text { Total opertaing } \\
\text { expenses }\end{array}$ & Dietsch and Lozano-Vivas (2000) \\
\hline
\end{tabular}




\begin{tabular}{|c|c|c|}
\hline Variable & Definition & Source \\
\hline $\begin{array}{l}\text { Non-interest } \\
\text { income ratio } \\
\text { (NIITA) }\end{array}$ & $\begin{array}{l}\text { Non interest income } \\
\text { to total assets }\end{array}$ & Claessens et al. (2001); Vennet (2002) \\
\hline NB & Number of branches & Authors' idea \\
\hline $\begin{array}{l}\text { Experience of } \\
\text { banks (Age) }\end{array}$ & $\begin{array}{l}\text { No. of years } \\
\text { commencing from } \\
\text { operation }\end{array}$ & Authors' idea. \\
\hline
\end{tabular}

\subsection{Econometric Model}

There has been a longstanding debate in measuring efficiency of a cost frontier. The methodologies can be classified broadly into two models, parametric and non-parametric. In the parametric model SFA, the Thick Frontier Approach (TFA) and Distribution Free Approach (DFA) are used. In non-parametric approaches linear programming techniques are applied such as DEA and Free Disposal Hull Analysis (FDHA) (Eisazadeh \& Shaeri, 2012). However, until today, researchers have reached no consensus about the best appropriate estimation methodology. In some studies, DEA method is applied because it is a non-parametric and deterministic method and, hence, does not need an anterior assumption about the analytical cost function. With DEA, multiple inputs and outputs of a complex cost or production function can be explained with a single efficiency indicator.

In our study, we used SFA because it has some advantages over DEA. First of all, the research output of decision-making units (DMU) are not fixed but affected by many random variables. Such random measurement errors are taken into account under SFA. Secondly, in SFA, the regression parameters and efficiency values are unbiasedly estimated in single step (Wang \& Schmidt, 2002). Thirdly, SFA mitigates the problem of explicit mitigation of a functional connection, because under this approach it is possible to test what production function fits the data best (Ehlers, 2011). Last but not least, hierarchically performance model development is possible by combining multi-level models with SFA.

For potential endogeneity problem, two step dynamic panel data approach was applied which was suggested by Arellano and Bover (1995) and Blundell and Bond (2000). We also applied dynamic panel GMM technique (Doytch \& Uctum, 2011) to correct potential heteroscedasticity, endogeneity and autocorrelation problems. The standard GMM estimator is known to be a consistent estimator of as $\mathrm{N}$ (the size of the units) approaches infinity. However, this standard GMM estimator has been found to have poor finite sample properties (bias) in the case in which the series is highly persistent (Blundell \& Bond, 1998). In these circumstances, the lagged levels of the series are only weakly correlated with subsequent first differences, thus leading to weak instruments for the firstdifferenced equations. Arellano and Bover (1995) and Blundell and Bond (1998) 
demonstrated that the System-GMM approach- by adding additional moment restrictions - permits lagged first differences to be used as instruments in the levels equations, and this corrects any bias that could emerge using the standard GMM estimator. Out of several GMM approaches, the two step feasible GMM is more popular, particularly for the System GMM. Before applying GMM, the variables were tested for their correlation, other tests like serial correlation test, test for heteroskedasticity, test for cross sectional dependence, test for endogeinity were conducted. Diagnosis tests like Sargan test, Arellano-Bond order 1 (2) test for first (second) order correlation for GMM estimator were also performed.

On the basis of literature review and our chosen variables, we developed the following econometric model to investigate the impact of potential determinants on CE of commercial banks in Bangladesh.

$$
\begin{aligned}
& \mathrm{CE}_{\mathrm{it}}=\alpha_{0}+\alpha_{1} \mathrm{CAR}_{\mathrm{it}}+\alpha_{2} \mathrm{Risk}_{\mathrm{it}}+\alpha_{3} \mathrm{CE}_{\mathrm{it}-1}+\alpha_{4} \mathrm{ROA}_{\mathrm{it}}+\alpha_{5} \mathrm{Size}_{\mathrm{it}}+\alpha_{6} \mathrm{TLTD}_{\mathrm{it}}+\alpha_{7} \mathrm{OWND}_{\mathrm{it}} \\
& +\alpha_{8} \mathrm{NB}_{\mathrm{it}}+\alpha_{9} \mathrm{OC}_{\mathrm{it}}+\alpha_{10} \text { NIITA }_{\mathrm{it}}+\alpha_{11} \mathrm{Age}_{\mathrm{it}}+\mathrm{e}_{\mathrm{it}}
\end{aligned}
$$

Here, subscript i represents the cross-sectional dimension across the bank and subscript $t$ represents the time dimension. Error term is represented by $e_{i t}$.

\subsection{Model Efficiency Test}

We conducted robustness checks to validate the empirical results of GMM estimators namely the Arellano-Bond Dynamic Panel Data Estimation. For testing the robustness, we made three changes in our independent variables. We used Equity to total assets (EQTTA) instead of CAR as a proxy for capital regulation, return on equity (ROE) instead of ROA as a proxy for profitability measure, loan loss provisions to non-performing loans (LLPNPL) instead of NPLTL as a proxy for risk measure. We used these three changes because these three variables are very crucial for the banking sector in Bangladesh. For instance, banks need to maintain minimum regulatory capital according to Basel III, and this capital regulation is introduced to control the risk taking behavior of banks. Finally, banks manager are responsible for the profit earning capacity of banks since their aim is to maximize the wealth of shareholders.

\section{Empirical Findings}

Results are derived from the econometric model in this section. In measuring CE, we used SFA model. To determine the degree of multicollinearity among the independent variables and the level of correlation between $\mathrm{CE}$ and its determinants, Pearson's correlation coefficient was used. In our further analysis, we used four different regression estimators - Ordinary Least Square (OLS), Panel Random/Fixed Effect (RE/FE) model, GMM specifically System dynamic panel data estimation and Arellano-Bond Dynamic Panel Data Estimation. We 
also used Hausman test to see whether panel FE/RE model was appropriate for our panel data (Aliyu \& Yusof, 2016; Hausman, 1978).

In addition, to test the existence of serial correlation, Wooldridge test for autocorrelation (Wooldridge, 1990) was applied. Breusch-Pagan/CookWeisberg test of heteroscedasticity was also used to support the RE requirement for balanced panel observation (Breusch \& Pagan, 1979; Cook \& Weisberg, 1982). To see cross sectional dependence of variables, we ran Pesaran's test (Pesaran, 2004). In addition, we performed a Hausman test of endogeneity in our measurement to find out whether there was endogeneity (Hausman \& Taylor, 1981). Finally, Sargan's test was carried out to show that the tools were valid (Sargan, 1958). This section is divided into three sub-sections. Section 1 reports on descriptive statistics, section 2 presents the correlation analysis and finally section 3 reports on the regression analysis.

\subsection{Descriptive Statistics}

Descriptive statistics of all variables, used in this study are reported in Table 3. The average value of efficiency was 1.108 or $110.8 \%$. The maximum value was 1.55 or $155 \%$ and the minimum value was 1.01 or $101 \%$. A value of more than $100 \%$ was referred to as cost inefficiency of banks in Bangladesh. The standard deviation (SD) of efficiency was $10.98 \%$ which indicated that efficiency varied very slightly from bank to bank.

Table 3. Descriptive Statistics

\begin{tabular}{lccccc}
\hline Variable & Mean & Std. Dev. & Minimum & Maximum & Observation \\
\hline CE & 1.108132 & 0.109836 & 1.01146 & 1.54623 & 264 \\
CAR & 13.63954 & 64.55062 & -108.49 & 102.500 & 264 \\
NPLTL & 0.085236 & 0.155629 & 0.0073 & 1.00000 & 264 \\
TLTD & 0.857377 & 0.508061 & 0.083489 & 0.88289 & 264 \\
ROA & 0.009769 & 0.015658 & -0.109182 & 0.05099 & 264 \\
NIITA & 0.028712 & 0.012360 & 0.002694 & 0.10110 & 264 \\
Age & 22.01515 & 9.892952 & 8.00000 & 45.0000 & 264 \\
OC & 4267.204 & 3225.439 & 455.3226 & 19579.57 & 264 \\
ROE & 0.121273 & 0.224974 & -2.74082 & 1.40864 & 264 \\
Size & 11.92754 & 0.763578 & 9.413911 & 13.9992 & 264 \\
\hline
\end{tabular}

Source: Authors' calculations. 
The average CAR was $13.64 \%$ which was higher than the minimum requirement of capital in Bangladesh i.e. $10 \%$ whereas the maximum value was $102.00 \%$ and the minimum value was $-108.49 \%$. The average credit risk (NPLTL) was $9 \%$ and it ranged from a minimum $0.07 \%$ to a maximum $100 \%$. The average total liabilities to total deposits was $85.73 \%$, whereas the maximum value was $88 \%$ and the minimum value was $83 \%$. The average ROA and ROE, which indicated profitability, was $0.97 \%$ and $12.12 \%$, respectively, which ranged from $-10.91 \%$ to $5.09 \%$ and $-274 \%$ to $140 \%$, respectively. Both of these varied slightly from bank to bank (SD was 0.016 and 0.22 , respectively).

The mean NIITA was $2.9 \%$ and it ranged from a minimum of $0.03 \%$ to a maximum of $10.11 \%$. The average age of bank was 22.01 years, whereas the maximum age was 45 years and the minimum age was 8 years. From the table it can also be seen that the average operating cost was 4267.20 million Bangladeshi taka, with a maximum value of 19579.57 million Bangladeshi taka and a minimum value of 455.32 million Bangladeshi taka. The table also shows that the mean size of banks (natural logarithm of total assets) was 11.927 and it ranged from a minimum of 9.415 to a maximum of 13.99 .

\subsection{Correlation}

The degree of correlation between variables used in the study is reported in Table 4. We used Pearson's correlation coefficient here. From the matrix, it can be seen that the correlations between the majority of the variables did not support the severe problem of multicollinearity, only OWND and NB variables showed the problem of multicollinearity, hence we did not report them in the correlation matrix.

It is noted that, multicollinearity exists when the correlation between two variables exceeds 0.80 (Kennedy, 2008). It can be seen from the table that the correlation coefficient between the independent variables were less than 0.80 . Therefore, it can be concluded that there is no multicollinearity problem in our case.

Table 4. Correlation Matrix for the Dependent and Independent Variables

\begin{tabular}{cccccccccc}
\hline & CE & CAR & NPLTL & ROA & TLTD & Age & NITA & OC & Size \\
& 1 & 2 & 3 & 4 & 5 & 6 & 7 & 8 & 9 \\
\hline 1 & 1.000 & & & & & & & & \\
2 & $-0.162^{* * *}$ & 1.000 & & & & & & & \\
3 & $0.453^{* * *}$ & $-0.114^{*}$ & 1.000 & & & & & & \\
4 & $-0.403^{* * *}$ & $0.116^{*}$ & $-0.750^{* * *}$ & 1.000 & & & & & \\
\hline
\end{tabular}

(continued) 


\begin{tabular}{cccccccccc}
\hline & CE & CAR & NPLTL & ROA & TLTD & Age & NITA & OC & Size \\
& 1 & 2 & 3 & 4 & 5 & 6 & 7 & 8 & 9 \\
\hline 5 & 0.005 & -0.057 & -0.055 & 0.031 & 1.000 & & & & \\
6 & 0.093 & 0.091 & $0.279^{* * *}$ & $-0.195^{* * *}$ & $-0.116^{*}$ & 1.000 & & & \\
7 & -0.048 & 0.091 & $-0.223^{* * *}$ & $0.428^{* * *}$ & -0.014 & 0.008 & 1.000 & & \\
8 & $0.137^{* *}$ & $0.318^{* * *}$ & 0.019 & -0.029 & -0.106 & $0.615^{* * *}$ & 0.025 & 1.000 & \\
9 & $-0.255^{* * *}$ & $0.268^{* * *}$ & $-0.281^{* * *}$ & $0.201^{* * *}$ & $-0.086^{*}$ & $0.553^{* * *}$ & 0.019 & $0.083^{* * *}$ & 1.000 \\
\hline
\end{tabular}

Note: The table shows the results of Pearson's Correlation Coefficient. ${ }^{* * * * *}$ and ${ }^{*}$ indicates significance at $1 \%, 5 \%$ and $10 \%$, respectively.

In addition, to examine the existence of multicollinearity, we used the Variance Inflation Factor (VIF) measures. The results are reported in Table 5 as follows. VIF is equal to $1 /$ Tolerance and it is always less than or equal to 1 . There is no formal VIF value for determining the presence of multicollinearity. Values of VIF that exceed 10 are often regarded as indicating multicollinearity (O’Brien, 2007).

In the VIF measure (Table 5), the VIF of NB variable was found to be at 11.70 which indicated there was existence of collinearity. Based on the correlation matrix and VIF figures, the NB and OWND variables were omitted in the regression analysis. In the case of other variables, the issue of multicollinearity did not subvert our results.

Table 5. Variance Inflation Factor

\begin{tabular}{lcc}
\hline Variable & VIF & $1 /$ VIF \\
\hline NB & 11.70 & 0.085489 \\
OWND & 7.83 & 0.127687 \\
Size & 5.75 & 0.173947 \\
OC & 5.19 & 0.192623 \\
NPLTL & 3.40 & 0.293878 \\
ROA & 2.85 & 0.351361 \\
Age & 2.82 & 0.354103 \\
NIITA & 1.34 & 0.748760 \\
CAR & 1.17 & 0.856657 \\
TLTD & 1.04 & 0.963078 \\
Mean VIF & 4.31 & \\
\hline
\end{tabular}




\subsection{Regression Analysis}

Table 6 demonstrates the outcome of GMM estimator where bank CE is the dependent variable. In the first case, we ran the regression using OLS regression where we assumed that all the assumptions of OLS were valid. In the second case, we applied Hausman test for panel FE or RE. In our Hausman test for panel FE or RE, we found that $\mathrm{p}$ value was greater than 0.05 , so we could not reject that the null hypothesis of RE was appropriate. Then we ran the regression by using panel RE model. The results are reported in Table 6.

In the third case, we determined whether the data had the problem of endogeneity, heteroscedasticity, autocorrelation and/or cross sectional dependency. The p-value from Hausman test for endogeneity was 0.000 which suggested that there was a problem of endogeneity where CAR and NPLTL were endogenous variables in the equation of CE. As a result, the OLS and RE panel model were not appropriate in our case. $\mathrm{P}$ values from the serial correlation test was 0.000 which indicated that the null hypothesis of no serial correlation was rejected. This meant that the error terms were serially correlated. In the BreuschPagan/Cook-Weisberg test for heteroscedasticity, the p-value was below an appropriate edge (i.e. $\mathrm{p}<0.05$ ), therefore the null hypothesis of homoscedasticity was rejected. For testing the presence of cross-sectional independence we took on Pesaran's test. Here, the p value was 0.000 , which indicated there was cross sectional dependency among variables. Based on the above test, the GMM data estimator was appropriate for our case. For the dynamic nature of data we used both System-Dynamic Panel Data Estimation and Arellano-Bond Dynamic Panel Data Estimation and the results are reported in Table 6.

It can be seen from Table 6 that the Arellano-Bond Dynamic Panel Data Estimation was appropriate for our case, because it showed better results than any other estimator. Hence, the outcome from the Arellano-Bond Dynamic Panel Data Estimation were presented in the next paras.

From Table 6, it can be seen that, the coefficient of capital was negative and it was statistically significant at $1 \%$ level of significance. This implied that capitalized banks are not as cost efficient as undercapitalized banks. In a developing country like Bangladesh, the cost of capital is more and therefore it is expensive to maintain more capital. Hence banks with high capital is less efficient. This finding is inconsistent with our hypothesis $\mathrm{H} 1$ and contrasts with findings by Hafez (2018).

The coefficient of risk (NPLTL) was negative and statistically significant at $1 \%$ level of significance. This states that banks with high risk are less cost efficient than banks having low risk. The negative sign also indicates that riskier banks are more cost inefficient. Bad management hypothesis becomes evident in that case. This outcome is unswerving to our preliminary hypothesis (H2) and is supported by Carvallo and Kasman (2005). Turning to the impact of bank profitability on $\mathrm{CE}$, it is evident that profitable banks are more cost efficient. They can organize their costs well which may in turn make them more profitable. This complies with our initial hypothesis (H3). 
Table 6. Determinants of CE

\begin{tabular}{|c|c|c|c|c|}
\hline Variable & OLS & Panel RE & $\begin{array}{l}\text { System-Dynamic } \\
\text { Panel Data } \\
\text { Estimation }\end{array}$ & $\begin{array}{l}\text { Arellano-Bond } \\
\text { Dynamic Panel } \\
\text { Data Estimation }\end{array}$ \\
\hline Constant & $2.4543^{* * * *}(14.94)$ & $1.168^{* * * *}(20.34)$ & $-0.04575^{* * *}(-4.91)$ & $-0.0499^{* * *}(-21.45)$ \\
\hline $\mathrm{CE}(-1)$ & - & - & $1.0327^{* * *}(1616.48)$ & $1.0549^{* * *}(748.73)$ \\
\hline CAR & $-0.0003^{* * *}(-4.10)$ & $-0.0004^{* * *}(-2.66)$ & $-3.39 \mathrm{e}-06^{* * *}(-9.19)$ & $-1.08 \mathrm{e}-06^{* * *}(-5.96)$ \\
\hline NPLTL & $0.05619(1.09)$ & $-0.0296^{* *}(-2.43)$ & $-0.00138^{* * * *}(-20.56)$ & $-0.0012^{* * *}(-9.09)$ \\
\hline ROA & $-0.8819^{*}(-1.86)$ & $0.2994^{* * * *}(2.82)$ & $0.02845^{* * *}(15.88)$ & $0.000762^{* * *}(2.83)$ \\
\hline TLTD & $-0.0010(-0.12)$ & $-0.00024(-0.14)$ & $-0.00005(-1.18)$ & $-0.0255^{* * * *}(-12.43)$ \\
\hline Age & $0.0023^{* * * *}(3.17)$ & $0.0079^{* * * *}(8.65)$ & $0.00022^{* * *}(11.24)$ & $0.01662^{* * * *}(6.16)$ \\
\hline NIITA & $0.4703(1.13)$ & $0.08821(071)$ & $0.03702^{* * *}(14.69)$ & $0.000207^{* * *}(6.08)$ \\
\hline $\mathrm{OC}$ & $0.0036^{* * *}(12.04)$ & $\begin{array}{c}-4.8 \mathrm{e}-06^{* * *} \\
(-5.52)\end{array}$ & $-5.6 \mathrm{e}-07^{* * *}(-15.04)$ & $-1.23 \mathrm{e}-07^{* * *}(-5.88)$ \\
\hline Size & $-0.139^{* * * *}(-10.05)$ & $-0.036^{* * *}(-6.38)$ & $-0.0034^{* * * *}(-88.52)$ & $-0.00074^{* * * *}(-6.07)$ \\
\hline xttest0 (p-value) & 0.0000 & - & - & - \\
\hline $\begin{array}{l}\text { Hausman Test } \\
\text { for Panel FE/RE } \\
\text { (p-value) }\end{array}$ & - & 0.5273 & - & - \\
\hline $\begin{array}{l}\text { Serial correlation } \\
\text { test (Wooldridge } \\
\text { test for } \\
\text { autocorrelation, } \\
\text { p-value) }\end{array}$ & - & - & 0.000 & 0.000 \\
\hline $\begin{array}{l}\text { Breusch-Pagan/ } \\
\text { Cook-Weisberg } \\
\text { test for } \\
\text { heteroscedasticity } \\
\text { (p-value) }\end{array}$ & - & - & 0.000 & 0.000 \\
\hline $\begin{array}{l}\text { Pesaran's test of } \\
\text { cross sectional } \\
\text { independence } \\
\text { (p-value) }\end{array}$ & - & - & 0.000 & 0.000 \\
\hline $\begin{array}{l}\text { Hausman test for } \\
\text { endogeneity F } \\
\text { (p-value) }\end{array}$ & - & - & $16.82(0.000)$ & $17.38(0.000)$ \\
\hline $\begin{array}{l}\text { Sargan's Test } \\
\text { (p-value) }\end{array}$ & - & - & 0.999 & 0.989 \\
\hline $\mathrm{AR}(1)$ & - & - & 0.26 & 0.24 \\
\hline $\operatorname{AR}(2)$ & - & - & 0.38 & 0.36 \\
\hline Observations & 264 & 264 & 264 & 264 \\
\hline Number of banks & 33 & 33 & 33 & 33 \\
\hline
\end{tabular}

Note: The table shows the empirical results from OLS, Panel RE, System GMM and Arellano-Bond estimation respectively. The dependent variable is cost efficiency (CE) in each case. ${ }^{* * * * *}$ and ${ }^{*}$ indicates significance at $1 \%, 5 \%$ and $10 \%$, respectively. T-statistics are shown in parentheses. CE(-1) indicates cost efficiency in lag one. 
The coefficient of TLTD was negative which indicated that more aggressive banks were involved in lending activities as compared to deposits and therefore were less cost efficient. In the case of developed countries, the scenario may be different (Ariff \& Luc, 2008). However, in the case of developing countries like Bangladesh, where people have a tendency to default on loans, a higher TLTD may hinder efficiency because it increases the cost related to cash collection.

As expected, experience (Age) had a positive and statistically significant impact on cost efficiency. The findings here supports our initial hypothesis (H4). It demonstrates that as the experience of banks increases, banks can manage their cost more efficiently. Experience theory and learning theory are effective in the case of banks in Bangladesh.

The coefficient between NIITA was positive and significant which indicated that banks which had more fee income, were more cost efficient. This may happen because this source of income is more stable and riskless than that of interest income.

It could also be seen from the results that the coefficient of operating cost was negative and statistically significant at $1 \%$ level of significance which implied that banks with high operating cost were less cost efficient. This outcome also supports our previous literature and our hypothesis (H5).

In respect of bank size, it was found that size had a negative and statistically significant impact on banks' CE which suggested that large banks were less cost efficient than those of small banks. One possible reason may be the inclusion of state owned banks in the data. In Bangladesh, state owned banks are large and hence found to be inefficient. Many control mechanisms help balance the interests of owners and managers in private commercial banks and improve their quality that is missing from state-owned commercial banks (e.g.: potentially higher exposure of private businesses to takeovers and subsequent job losses, etc.) (Fama, 1980; Perera et al.; 2007). Moreover, managers of stateowned companies may be inclined to follow their own interests or the interests of lobbyists to the detriment of those of the company (di Patti \& Hardy, 2005; Perera et al., 2007). Our outcomes supported Ariff and Luc (2008) and Berger et al. (2009), but contradicted that of Xiaogang et al. (2005). This finding does not support our hypothesis (H6).

Finally, the coefficient of CE(-1) was positive and significant at $1 \%$ level of significance which meant that cost efficiency of the current year was also the result of previous year's cost efficiency. It meant that banks' cost efficiency showed persistent results which suggested that banks with high efficiency in the previous year(s) were also efficient in the current year. This result supports our hypothesis (H7).

Diagnostic tests of GMM estimator in all cases showed that the models were accurately specified. For instance, the p-values of Sargan's tests were 
insignificant, indicating that the null hypothesis that instruments which were not exogeneous were not rejected and confirmed that the instruments used were valid. Similarly, the insignificant AR(2) p-values confirmed that there was no second-order serial correlation in residuals.

\subsection{Model Efficiency and Robustness Test}

We conducted robustness checks to validate the empirical results of GMM estimators and the estimated results were reported in the following Table 7. After replacing those three variables as mentioned in the methodology section, we tested our data again for the existence of multicollinearity, serial correlation, heteroscedasticity and cross section dependence and endogeneity problems.

The results showed that there was no problem of multicollinearity. Null hypotheses of no serial correlation, homoscedasticity in error terms, no endogeneity and cross sectional independence were rejected. Therefore, we applied only GMM estimation. The model showed similar results and was consistent with Table 6 in its association with the determinants of CE. In terms of the level of significance of all factors, we also found similarities with some exceptions for the t-value. Similar to Table 6, we found that all the variables were highly significantly related with $\mathrm{CE}$ in Bangladesh. Hence, we can conclude that our model for determinants of $\mathrm{CE}$ is robust for different measures of variables.

Table 7. Determinants of Cost Efficiency (Arellano-Bond Dynamic Panel Data Estimation)

\begin{tabular}{lc}
\hline Variable & Coefficient \\
\hline Constant & $-0.3189^{* * *}(-18.51)$ \\
CE(-1) & $0.9849^{* * *}(81.29)$ \\
EQTTA & $-1.07 \mathrm{e}-05^{* * *}(-6.18)$ \\
LLPNPL & $-0.0035^{* * *}(-8.07)$ \\
ROE & $0.000892^{* * *}(3.38)$ \\
TLTD & $-0.02093^{* * *}(-13.58)$ \\
Age & $0.01776^{* * *}(7.19)$ \\
NIITA & $0.000309^{* * *}(7.06)$ \\
OC & $-1.54 \mathrm{e}-06^{* * *}(-6.76)$ \\
Size & $-0.00087^{* * *}(-7.04)$ \\
Serial correlation test (Wooldridge test for autocorrelation, & \\
p-value) & 0.000 \\
\hline
\end{tabular}




\begin{tabular}{lc}
\hline Variable & Coefficient \\
\hline $\begin{array}{l}\text { Breusch-Pagan/Cook-Weisberg test for heteroscedasticity } \\
\text { (p-value) }\end{array}$ & 0.000 \\
Pesaran's test of cross sectional independence (p-value) & 0.000 \\
Hausman test for endogeneity F (p-value) & $21.56(0.000)$ \\
Sargan's Test (p-value) & 0.765 \\
AR(1) & 0.28 \\
AR(2) & 0.50 \\
Observations & 264 \\
Number of banks & 33 \\
\hline
\end{tabular}

Note: The table shows the empirical results from Arellano-Bond estimation respectively. The dependent variable is cost efficiency (CE). ${ }^{* * *},{ }^{* *}$ and ${ }^{*}$ indicates significance at $1 \%$, $5 \%$ and $10 \%$, respectively. t-statistics are shown in parentheses. $\mathrm{CE}(-1)$ indicates cost efficiency in lag one.

\section{Conclusion and Recommendation}

This study empirically examined the factors affecting CE for the latest data set of Bangladeshi banks for the period from 2009 to 2016. Empirical results showed that among the pooled OLS, FE or RE panel regression, System-Dynamic Panel Data Estimation and Arellano-Bond Dynamic Panel Data Estimation, the Arellano-Bond Dynamic Panel Data Estimation was the most suited for our data which had problems of endogeneity, heteroscedasticity, serial correlation and cross sectional dependence.

The empirical results showed that capitalized banks were not as cost efficient as undercapitalized banks. In a developing country like Bangladesh, it is expensive to maintain more capital. Hence banks with high capital is less efficient. It is also evident that banks with high risk are less cost efficient than banks having low risk. As a result, bad management hypothesis becomes evident in this case.

The results also showed that profitable banks were more cost efficient as they could organize their cost well which would in turn make them more profitable. While more aggressive banks which were involved in more lending activities as compared to deposits were less cost efficient. In Bangladesh, people have a tendency to default on loans, thus a higher TLTD may hinder efficiency because it increases the loss and cost.

It was also observed from the results that experienced banks were more cost efficient which supported the experience theory and learning theory. Results also stated that banks with more non-interest income were more cost efficient 
than those with lower non-interest income. This is because this source of income is more stable and riskless than that of interest income. It can also be seen from the results that banks with high operating cost were less cost efficient. In respect of bank size, it was found that large banks were less cost efficient than those of small banks. One possible reason may be the inclusion of state owned banks in the data. In Bangladesh, state owned banks are large and hence found to be inefficient. Finally, CE of the current year is also the result of previous year's CE which indicates the persistency in $\mathrm{CE}$ of banks in Bangladesh.

The empirical results from the current study provides considerable policy applications. Policymakers should exercise caution in designing regulatory capital as this could decrease the efficiency of banks and they also focus on aggressiveness of banks in providing loans so that bad loans. The bank manager should diversify banking activities to generate non-interest income from commissions, charges, etc. Policymakers and regulators should also focus on monitoring the operating efficiency of banks and to consider all potential technologies to reduce operating costs of Bangladeshi banks. In terms of the management of large banks, their operations should be scaled down to become more efficient. In addition, the government should focus specifically on stateowned banks and that inexperienced banks can be merged with experienced ones to benefit from the experience and learning effect. Finally, policymakers should also concentrate on efficient banks so that they can continuously maintain their efficiency. It would be difficult to raise more revenue in a small economy with 58 banks in Bangladesh, thus they must be efficient in managing their resources and costs.

One needs to be cautious, in comparing the results of previous studies that evaluates the determinants of banks' $\mathrm{CE}$ in developed countries as this literature is still in its infancy. Further areas of research should seek to evaluate the consistency of our findings by way of application to a more representative and contemporary sample of banks in developed countries. The approach could also be expanded to examine the consistency of results by using alternative measures of efficiency like DEA and by using alternative accounting measures of the variables as well as by including some other determinants.

\section{References}

Ab-Rahim, R., Md-Nor, N. G., Ramlee, S., \& Ubaidillah, N. Z. (2012). Determinants of cost efficiency in Malaysian Banking. International Journal of Business \& Society, 13(3).

Abdul-Majid, M., Saal, D. S., \& Battisti, G. (2011a). Efficiency and total factor productivity change of Malaysian commercial banks. The Service Industries Journal, 31(13), 2117-2143. 
Abdul-Majid, M., Saal, D. S., \& Battisti, G. (2011b). The impact of Islamic banking on the cost efficiency and productivity change of Malaysian commercial banks. Applied Economics, 43(16), 2033-2054.

Aigner, D., Lovell, C. A. K., \& Schmidt, P. (1977). Formulation and estimation of stochastic frontier production function models. Journal of Econometrics, $6(1), 21-37$.

Alam, N. (2012). The impact of regulatory and supervisory structures on bank risk and efficiency: Evidence from dual banking system. Asian Journal of Finance \& Accounting, 4(1), 216-244.

Aliyu, S., \& Yusof, R. M. (2016). Profitability and cost efficiency of Islamic banks: A panel analysis of some selected countries. International Journal of Economics and Financial Issues, 6(4), 1736-1743.

Altunbas, Y., Carbo, S., Gardener, E. P., \& Molyneux, P. (2007). Examining the relationships between capital, risk and efficiency in European banking. European Financial Management, 13(1), 49-70.

Altunbaş, Y., Gardener, E. P., Molyneux, P., \& Moore, B. (2001). Efficiency in European banking. European Economic Review, 45(10), 1931-1955.

Altunbas, Y., Liu, M.-H., Molyneux, P., \& Seth, R. (2000). Efficiency and risk in Japanese banking. Journal of Banking \& Finance, 24(10), 1605-1628.

Andrieş, A. M., \& Căpraru, B. (2014). The nexus between competition and efficiency: The European banking industries experience. International Business Review, 23(3), 566-579.

Anwar, M. (2015). Bank efficiency and lending propensity: Evidence from commercial banks in Indonesia. Doctoral dissertation, School of Management.

Arellano, M., \& Bover, O. (1995). Another look at the instrumental variable estimation of error-components models. Journal of econometrics, 68(1), 29-51.

Ariff, M., \& Luc, C. (2008). Cost and profit efficiency of Chinese banks: A nonparametric analysis. China Economic Review, 19(2), 260-273.

Ataullah, A., \& Le, H. (2006). Economic reforms and bank efficiency in developing countries: The case of the Indian banking industry. Applied Financial Economics, 16(9), 653-663.

Avkiran, N. K. (2006). Developing foreign bank efficiency models for DEA grounded in finance theory. Socio-Economic planning sciences, 40(4), 275-296.

Avkiran, N. K. (2011). Association of DEA super-efficiency estimates with financial ratios: Investigating the case for Chinese banks. Omega, 39(3), 323-334.

Banna, H., Ahmad, R., \& Koh, E. H. (2017). Determinants of commercial banks' efficiency in Bangladesh: Does crisis matter? The Journal of Asian Finance, Economics and Business (JAFEB), 4(3), 19-26. 
Battaglia, F., Farina, V., Fiordelisi, F., \& Ricci, O. (2010). The efficiency of cooperative banks: The impact of environmental economic conditions. Applied Financial Economics, 20(17), 1363-1376.

Battese, G. E., Heshmati, A., \& Hjalmarsson, L. (2000). Efficiency of labour use in the Swedish banking industry: A stochastic frontier approach. Empirical Economics, 25(4), 623-640.

Berger, A. N., \& DeYoung, R. (1997). Problem loans and cost efficiency in commercial banks. Journal of Banking \& Finance, 21(6), 849-870.

Berger, A. N., \& Hannan, T. H. (1998). The efficiency cost of market power in the banking industry: A test of the "quiet life" and related hypotheses. Review of economics and statistics, 80(3), 454-465.

Berger, A. N., Hasan, I., \& Zhou, M. (2009). Bank ownership and efficiency in China: What will happen in the world's largest nation? Journal of Banking \& Finance, 33(1), 113-130.

Berger, A. N., \& Mester, L. J. (1997). Inside the black box: What explains differences in the efficiencies of financial institutions? Journal of Banking \& Finance, 21(7), 895-947.

Bitar, M., Pukthuanthong, K., \& Walker, T. (2018). The effect of capital ratios on the risk, efficiency and profitability of banks: Evidence from OECD countries. Journal of International Financial Markets, Institutions and Money, 53, 227-262.

Blejer, M. I. (2006). Economic growth and the stability and efficiency of the financial sector. Journal of Banking \& Finance, 30(12), 3429-3432.

Blundell, R., \& Bond, S. (1998). Initial conditions and moment restrictions in dynamic panel data models. Journal of econometrics, 87(1), 115-143.

Blundell, R., \& Bond, S. (2000). GMM estimation with persistent panel data: An application to production functions. Econometric reviews, 19(3), 321-340.

Boot, A. W., \& Thakor, A. V. (1997). Banking scope and financial innovation. The Review of Financial Studies, 10(4), 1099-1131.

Breusch, T. S., \& Pagan, A. R. (1979). A simple test for heteroscedasticity and random coefficient variation. Econometrica: Journal of the Econometric Society, 1287-1294.

Bush, G. (2015). Learning by Banking: Testing for Experience Effects in the Financial Sector. Available at SSRN 2688578.

Carvallo, O., \& Kasman, A. (2005). Cost efficiency in the Latin American and Caribbean banking systems. Journal of International Financial Markets, Institutions and Money, 15(1), 55-72.

Chan, S. G., Karim, M. Z. A., Burton, B., \& Aktan, B. (2014). Efficiency and risk in commercial banking: Empirical evidence from East Asian countries. The European Journal of Finance, 20(12), 1114-1132. 
Chang, T. C., \& Chiu, Y. H. (2006). Affecting factors on risk-adjusted efficiency in Taiwan's banking industry. Contemporary Economic Policy, 24(4), 634-648.

Chiu, Y.-H., Chen, Y.-C., \& Bai, X.-J. (2011). Efficiency and risk in Taiwan banking: SBM super-DEA estimation. Applied Economics, 43(5), 587602.

Chiu, Y.-H., Jan, C., Shen, D.-B., \& Wang, P.-C. (2008). Efficiency and capital adequacy in Taiwan banking: $\mathrm{BCC}$ and super-DEA estimation. The Service Industries Journal, 28(4), 479-496.

Chortareas, G. E., Girardone, C., \& Ventouri, A. (2009). Efficiency and productivity of Greek banks in the EMU era. Applied Financial Economics, 19(16), 1317-1328.

Chortareas, G. E., Girardone, C., \& Ventouri, A. (2012). Bank supervision, regulation, and efficiency: Evidence from the European Union. Journal of Financial Stability, 8(4), 292-302.

Christopoulos, D. K., Lolos, S. E., \& Tsionas, E. G. (2002). Efficiency of the Greek banking system in view of the EMU: A heteroscedastic stochastic frontier approach. Journal of Policy Modeling, 24(9), 813-829.

Čiković, K. F., \& Cvetkoska, V. (2018). Efficiency of the Macedonian banking sector: A parametric approach. CEA Journal of Economics, 12(2), 1726.

Claessens, S., Demirgüç-Kunt, A., \& Huizinga, H. (2001). How does foreign entry affect domestic banking markets? Journal of Banking \& Finance, 25(5), 891-911.

Coelli, T. J. (1996). A Guide to FRONTIER Version 4.1 : A Computer Program for Stochastic Frontier Production and Cost Function Estimation.7, 1-33, CEPA Working Papers.

Cook, R. D., \& Weisberg, S. (1982). Residuals and influence in regression. New York: Chapman and Hall.

Das, A., \& Ghosh, S. (2009). Financial deregulation and profit efficiency: A nonparametric analysis of Indian banks. Journal of Economics and Business, 61(6), 509-528.

Deelchand, T., \& Padgett, C. (2009a). The Relationship between Risk, Capital and Efficiency: Evidence from Japanese Cooperative Banks. ICMA Centre Discussion Papers in Finance, DP2009-12.

Deelchand, T., \& Padgett, C. (2009b). The relationship between risk, capital and efficiency: Evidence from Japanese cooperative banks. Capital and Efficiency: Evidence from Japanese Cooperative Banks (December 18, 2009).

di Patti, E. B., \& Hardy, D. C. (2005). Financial sector liberalization, bank privatization, and efficiency: Evidence from Pakistan. Journal of Banking \& Finance, 29(8-9), 2381-2406. 
Dietsch, M., \& Lozano-Vivas, A. (2000). How the environment determines banking efficiency: A comparison between French and Spanish industries. Journal of Banking \& Finance, 24(6), 985-1004.

Dong, Y., Hamilton, R., \& Tippett, M. (2014). Cost efficiency of the Chinese banking sector: A comparison of stochastic frontier analysis and data envelopment analysis. Economic Modelling, 36, 298-308.

Doytch, N., \& Uctum, M. (2011). Does the worldwide shift of FDI from manufacturing to services accelerate economic growth? A GMM estimation study. Journal of International Money and Finance, 30(3), 410-427.

Drake, L., \& Hall, M. J. (2003). Efficiency in Japanese banking: An empirical analysis. Journal of Banking \& Finance, 27(5), 891-917.

Ehlers, R. S. (2011). Comparison of Bayesian models for production efficiency. Journal of Applied Statistics, 38(11), 2433-2443.

Eisazadeh, S., \& Shaeri, Z. (2012). An analysis of bank efficiency in the Middle East and North Africa. The International Journal of Banking and Finance, $9(4), 28-47$.

Esho, N. (2001). The determinants of cost efficiency in cooperative financial institutions: Australian evidence. Journal of Banking \& Finance, 25(5), 941-964.

Faccio, M., Marchica, M.-T., \& Mura, R. (2016). CEO gender, corporate risktaking, and the efficiency of capital allocation. Journal of Corporate Finance, 39, 193-209.

Fama, E. F. (1980). Agency problems and the theory of the firm. Journal of political economy, 88(2), 288-307.

Färe, R., Grosskopf, S., \& Weber*, W. L. (2004). The effect of risk-based capital requirements on profit efficiency in banking. Applied Economics, 36(15), 1731-1743.

Fethi, M. D., \& Pasiouras, F. (2010). Assessing bank efficiency and performance with operational research and artificial intelligence techniques: A survey. European journal of operational research, 204(2), 189-198.

Fiordelisi, F., \& Mare, D. S. (2013). Probability of default and efficiency in cooperative banking. Journal of International Financial Markets, Institutions and Money, 26, 30-45.

Fiordelisi, F., Marques-Ibanez, D., \& Molyneux, P. (2011). Efficiency and risk in European banking. Journal of Banking \& Finance, 35(5), 1315-1326.

Fioretti, G. (2007). The organizational learning curve. European Journal of Operational Research, 177(3), 1375-1384.

Fries, S., \& Taci, A. (2005). Cost efficiency of banks in transition: Evidence from 289 banks in 15 post-communist countries. Journal of Banking \& Finance, 29(1), 55-81. 
Gardener, E., Molyneux, P., \& Nguyen-Linh, H. (2011). Determinants of efficiency in South East Asian banking. The Service Industries Journal, 31(16), 2693-2719.

Garza-García, J. G. (2012). Determinants of bank efficiency in Mexico: A twostage analysis. Applied Economics Letters, 19(17), 1679-1682.

Girardone, C., Molyneux, P., \& Gardener, E. P. (2004). Analysing the determinants of bank efficiency: The case of Italian banks. Applied Economics, 36(3), 215-227.

Hafez, H. M. M. (2018). Examining the Relationship between Efficiency and Capital Adequacy Ratio: Islamic versus Conventional Banks-An Empirical Evidence on Egyptian Banks. Accounting and Finance Research, 7(2), 232.

Hall, M. J., \& Simper, R. (2013). Efficiency and competition in Korean banking. Applied Financial Economics, 23(10), 881-890.

Hammim, M., Abdullah, N., \& Al-Habshi, S. (2006). Efficiency of Islamic banks in Malaysia: A stochastic frontier approach. Journal of Economic Cooperation among Islamic Countries, 27(2), 37-70.

Han, Y., Kim, M. H., \& Kim, W.-J. (2012). Determinants of profit efficiency: Evidence from Korean savings banks. Applied Financial Economics, 22(12), 1003-1016.

Hasan, I., \& Marton, K. (2003). Development and efficiency of the banking sector in a transitional economy: Hungarian experience. Journal of Banking \& Finance, 27(12), 2249-2271.

Hassan, M., \& Hassan, M. (2018). Cost efficiency of banking sector of Bangladesh: Evidence using the stochastic frontier analysis. Asian Journal of Empirical Research, 8(6), 208-224.

Hauner, D. (2005). Explaining efficiency differences among large German and Austrian banks. Applied Economics, 37(9), 969-980.

Hausman, J. A. (1978). Specification tests in econometrics. Econometrica: Journal of the Econometric Society, 1251-1271.

Hausman, J. A., \& Taylor, W. E. (1981). A generalized specification test. Economics Letters, 8(3), 239-245.

Hughes, J. P., \& Mester, L. J. (2008). Efficiency in banking: Theory, practice, and evidence.

Isik, I., \& Hassan, M. K. (2003). Efficiency, ownership and market structure, corporate control and governance in the Turkish banking industry. Journal of Business Finance \& Accounting, 30(9-10), 1363-1421.

Jondrow, J., Knox Lovell, C. A., Materov, I. S., \& Schmidt, P. (1982). On the estimation of technical inefficiency in the stochastic frontier production function model. Journal of Econometrics, 19(2-3), 233-238.

Kasman, A., \& Yildirim, C. (2006). Cost and profit efficiencies in transition banking: The case of new EU members. Applied Economics, 38(9), 1079-1090. 
Kenjegalieva, K. A., Simper, R., \& Weyman-Jones, T. G. (2009). Efficiency of transition banks: Inter-country banking industry trends. Applied Financial Economics, 19(19), 1531-1546.

Kennedy, P. (2008). A guide to econometrics. Malden, Mass: Blackwell Publishing.

Khanam, D., \& Nghiem, H. S. (2006). Efficiency of banks in Bangladesh: A nonparametric approach. Regional Studies-Islamabad, 25(1), 93.

Koetter, M. (2008). The stability of bank efficiency rankings when risk preferences and objectives are different. European Journal of Finance, 14(2), 115-135.

Kohers, T., Huang, M.-H., \& Kohers, N. (2000). Market perception of efficiency in bank holding company mergers: The roles of the DEA and SFA models in capturing merger potential. Review of Financial Economics, 9(2), 101120.

Kraft, E., \& Tirtıroğlu, D. (1998). Bank efficiency in Croatia: A stochasticfrontier analysis. Journal of comparative economics, 26(2), 282-300.

Kumbhakar, S. C., \& Tsionas, E. G. (2008). Scale and efficiency measurement using a semiparametric stochastic frontier model: Evidence from the US commercial banks. Empirical Economics, 34(3), 585-602.

Kwan, S., \& Eisenbeis, R. A. (1997). Bank risk, capitalization, and operating efficiency. Journal of financial services research, 12(2-3), 117-131.

Kyj, L., \& Isik, I. (2008). Bank x-efficiency in Ukraine: An analysis of service characteristics and ownership. Journal of Economics and Business, 60(4), 369-393.

Lee, C.-C., Hsieh, M.-F., \& Yang, S.-J. (2014). The relationship between revenue diversification and bank performance: Do financial structures and financial reforms matter? Japan and the World Economy, 29, 18-35.

Manlagñit, M. C. V. (2011). Cost efficiency, determinants, and risk preferences in banking: A case of stochastic frontier analysis in the Philippines. Journal of Asian Economics, 22(1), 23-35.

Maudos, J., Pastor, J. M., Pérez, F., \& Quesada, J. (2002). Cost and profit efficiency in European banks. Journal of international financial Markets, Institutions and Money, 12(1), 33-58.

Miah, M. D., \& Sharmeen, K. (2015). Relationship between capital, risk and efficiency: A comparative study between Islamic and conventional banks of Bangladesh. International Journal of Islamic and Middle Eastern Finance and Management, 8(2), 203-221.

Nail, L., \& Parisi, F. (2005). Bank mergers and their impact: A survey of academic studies: There seems to be no clear or universal silver bullet for postmerger success in banking as presented in empirical studies. Bank Accounting \& Finance, 18(4), 3-11. 
O'Brien, R. M. (2007). A caution regarding rules of thumb for variance inflation factors. Quality \& quantity, 41(5), 673-690.

Perera, S., Skully, M., \& Wickramanayake, J. (2007). Cost efficiency in South Asian banking: The impact of bank size, state ownership and stock exchange listings. International Review of Finance, 7(1-2), 35-60.

Pesaran, M. H. (2004). General diagnostic tests for cross section dependence in panels.

Podpiera, A., \& Podpiera, J. (2005). Deteriorating cost efficiency in commercial banks signals an increasing risk of failure: Czech National Bank.

Ray, S. C., \& Das, A. (2010). Distribution of cost and profit efficiency: Evidence from Indian banking. European Journal Of Operational Research, 201(1), 297-307.

Sargan, J. D. (1958). The estimation of economic relationships using instrumental variables. Econometrica: Journal of the Econometric Society, 393-415.

Sarkar, S., Sensarma, R., \& Sharma, D. (2019). The relationship between risk, capital and efficiency in Indian banking: Does ownership matter? Journal of Financial Economic Policy, 11(2), 218-231.

Schmidt, P., \& Lovell, C. K. (1979). Estimating technical and allocative inefficiency relative to stochastic production and cost frontiers. Journal of Econometrics, 9(3), 343-366.

Schulz, K. M., Molenda-Figueira, H. A., \& Sisk, C. L. (2009). Back to the future: The organizational-activational hypothesis adapted to puberty and adolescence. Hormones and behavior, 55(5), 597-604.

Schumpeter, J. A. (1982). The theory of economic development: An inquiry into profits, capital, credit, interest, and the business cycle (1912/1934). Transaction Publishers. 1982, January, 1, 244.

Sealey, C. W., \& Lindley, J. T. (1977). Inputs, outputs, and a theory of production and cost at depository financial institutions. The Journal of Finance, 32(4), 1251-1266.

Spulbăr, C., \& Niţoi, M. (2014). Determinants of bank cost efficiency in transition economies: Evidence for Latin America, central and Eastern Europe and South-East Asia. Applied Economics, 46(16), 1940-1952.

Staikouras, C., Mamatzakis, E., \& Koutsomanoli-Filippaki, A. (2008). Cost efficiency of the banking industry in the South Eastern European region. Journal of International Financial Markets, Institutions and Money, 18(5), 483-497.

Sun, L., \& Chang, T.-P. (2011). A comprehensive analysis of the effects of risk measures on bank efficiency: Evidence from emerging Asian countries. Journal of Banking \& Finance, 35(7), 1727-1735.

Tecles, P. L., \& Tabak, B. M. (2010). Determinants of bank efficiency: The case of Brazil. European Journal of Operational Research, 207(3), 15871598. 
Teplitz, C. J. (1991). The learning curve deskbook: A reference guide to theory, calculations, and applications: Quorum Books.

Vennet, R. V. (2002). Cost and profit efficiency of financial conglomerates and universal banks in Europe. Journal of Money, Credit and Banking, 254282.

Wang, H.-J., \& Schmidt, P. (2002). One-step and two-step estimation of the effects of exogenous variables on technical efficiency levels. Journal of Productivity Analysis, 18(2), 129-144.

Wezel, T. (2010). Bank efficiency amid foreign entry: Evidence from the Central American region: International Monetary Fund.

Wooldridge, J. M. (1990). A note on the Lagrange multiplier and F-statistics for two stage least squares regressions. Economics Letters, 34(2), 151-155.

Wright, T. P. (1936). Factors affecting the cost of airplanes. Journal of the Aeronautical Sciences, 3(4), 122-128.

Xiaogang, C., Skully, M., \& Brown, K. (2005). Banking efficiency in China: Application of DEA to pre-and post-deregulation eras: 1993-2000. China Economic Review, 16(3), 229-245.

Xiaoqing Maggie, F. U., \& Heffernan, S. (2007). Cost X-efficiency in China's banking sector. China Economic Review, 18(1), 35-53.

Zhang, J., Wang, P., \& Qu, B. (2012). Bank risk taking, efficiency, and law enforcement: Evidence from Chinese city commercial banks. China Economic Review, 23(2), 284-295.

Zheng, C., Gupta, A. D., \& Moudud-Ul-Huq, S. (2018). Effect of human capital efficiency on bank risk-taking behavior and capital regulation: Empirical evidence from a developing country. Asian Economic and Financial Review, 8(2), 231-247. 